\title{
Chagas Infection Transmission Control: Situation of Transfusional Transmission in Brazil and other Countries of Latin America
}

\author{
Helio Moraes-Souza
}

\author{
Coordenação de Sangue e Hemoderivados, SPS, MS e Hemocentros Regional de Uberaba, Fundação \\ Hemominas, Esplanada dos Ministérios, Bloco G, 6º Andar, 70058-900 Brasília, DF, Brasil
}

The transmission of the transfusion-associated Chagas disease is an important mechanism of its dissemination in several Latin American countries. The transmission risk depends on five factors: prevalence of infection in blood donors, degree of serological coverage, sensibility of used tests, safety of obtained results and infection risk. The Southern Cone Iniciative set off by the Pan-American Health Organization, in 1991, is contributing to the implementation of blood law in each endemic country, and to reduce the risk of transfusional transmission of this horrible disease. Despite the clear improvement of Brasilian hemotherapy after 1980 (with the creation of the Blood National Program - Pró-Sangue) and the significant reduction of the chagasic infection among its blood donors; socio-economic, politic and cultural unlevels, prevent it from reaching the necessary universality and security. In order to assure both, the Brazilian Ministry of Health decided to restructure its blood system. In May, 1998, a great program was launched, to reach a specific goal: Blood - 100\% with quality safety in all its process until 2003. It was divided in 12 projects, intends to guarantee the quality and self sufficiency in blood and hemoderivates.

Key words: Chagas disease by transfusion - blood transfusion - Chagas disease - control measure

When Carlos Justiano das Chagas discovered a human disease caused by Trypanosoma cruzi, 90 years ago, a continental tragedy was opened and unfortunately is enduring until our days.

Despite there is no current inquiry, covering all endemic area in American Continent, it is estimated that there are approximately 15 million to 18 million T. cruzi infected individuals; $60 \%$ living in urban areas and 50\% of this group is in latent period, therefore are blood donors in potential (Schmunis 1991, Moncayo 1992, Moraes-Souza \& Bordin 1996, Dias \& Schofield 1998).

The possibility of blood transfusion as a route of Chagas disease transmission had been insinuated six decades ago (Mazza et al. 1936) and confirmed approximately 50 years ago (Freitas et al. 1952) when control measures were proposed, which are up-to-date until our days (Soto 1940, Pellegrino 1949, Nussenzweig et al. 1953, MoraesSouza \& Bordin 1996). Nowadays, the estimated transmission risk of nosology for each unit of infected blood transfusion is about 14 to $49 \%$ (Schmunis 1991).

Fax: +55-61-447.1672

Received 9 June 1999

Accepted 9 August 1999
Despite the awareness about this problem complexity and the mechanisms to control it, the knowledge about the actual situation of hemotherapy and transfusional Chagas disease in Brazil and Latin America, till early 80's, was practically restrict to isolated serological inquiries and to few reports related by the infected blood receivers. The first Brazilian study that tried to analyze the problem in a more complex way, was developed by the Secretary of Health in the State of Minas Gerais. According to the above mentioned inquiry, made in 613 of the 723 existing cities and towns, only 268 (43.7\%) performed blood transfusion and, only 121 $(41.5 \%)$ of them, carried on the serological screening to Chagas disease in their donors (Dias \& Brener 1984).

In spite of prohibiting the paid donation, introducing the Blood National Program by Brazilian Government, in April 1980 (Portaria no. 07/80) and required the compulsory need of performing two serological screening testes anti-T. cruzi for donors, till the end of the 80's, it was not known the true situation of hemotherapy in Brazil. We were stimulated by this situation to carry out a large national inquiry. In this inquiry, 850 communities and 22 states were analyzed. From them, 585 (68.8\%) conducted blood transfusion, involving 1,525 hospitals and/or hemotherapy services; $44.5 \%$ performed only urgency transfusion and $42.2 \%$ transfused 
only total blood. Serological screening for Chagas disease, syphilis, B hepatitis, Aids and malaria was performed, respectively, by $68.8 \%, 75.2 \%, 65.4 \%$, $53.8 \%$ and $26 \%$ of all services. Particularly related to Chagas disease, we observed that the range of covering varied according to the studied city's population, being it of $33.3 \%$ in cities that have around 10 thousand inhabitants, $68.2 \%$ between 10 and 50 thousand and $92.5 \%$ in that cities with more than 50 thousand inhabitants. We were also able to see that $53.3 \%$ of services that tested their donors achieved only one single serological test for the T. cruzi, the covering of the public blood services was only $13 \%$ and arm-to-arm transfusion was performed by $18 \%$ of all services (Moraes Souza et al. 1994).

\section{CONTROL MEASURES}

The eradication of the main vector of $T$. cruzi to man, Triatoma infestants, in spite of being the most efficient form to reduce human infection, does not present immediate result in reducing and/or controlling transfusion-associated Chagas disease. The reason is that an individual infected during his childhood or adolescence, that maintains the asymptomatic phase of the disease, could be a potential donor till 60 years old according to current Brazilian Legislation or until 65, as some other countries regulation and will be added to Mercosul agreement (Portaria 1376/93 and Resolução 130/ Mercosul).

This important job of eradicating the vector, associated with control measures of hemotherapy services level, have resulted positively in the reduction of infected blood donors number. So, in the early 80's the average prevalence of positive results for T. cruzi in Brazil was 7.\% and in the other countries it was 6.8\% (Moraes-Souza 1985). In the 90's (two decades after the introduction of the main vector control programs), these index decreased respectively to $3.2 \%$ and $2.6 \%$, despite of very high values as $62.1 \%$ were found in one of the countries analyzed, in which the disease control had not been introduced (Schmunis 1991, Dias \& Schofield 1998).

Obviously, like any other transmissible nosology by blood transfusion, the transfusional transmission control of Chagas disease, is more directly linked to the selection of the donor and the blood, than to natural mechanisms of transmission and/or the vector itself.

There are three basic measures to prevent transfusional transmission of Chagas disease: the judicious selection of the candidate as donor; serological screening tests, specific and reproducible (serologic survey) and the treatment of the collected blood with gentian violet (Moraes-Souza \& Bordin 1996).

\section{TRANSMISSION RISK}

The probability of concerning Chagas disease through blood transfusion, depends on five factors: prevalence of infection in blood donors, degree of serological coverage, sensibility of used tests, safety of obtained results and risk of infection.

Schumuñis and colleagues (1998), when studied the infectivity risk for transfusion-transmitted of infectious diseases through blood transfusion in twelve countries of Central and South America, found, considering the factors referred above, values ranged from $2.06 \times 10^{4}$ (in Equador) to 219.28 x $10^{4}$ (in Bolivia). Based on these parameters, on the 1988 National Inquire data (Moraes-Souza et al. 1994); on the current prevalence infection among donors $(0.8 \%$ - 1997 data) and on the results of the sanitary surveillance in hemotherapy services (less than $2 \%$ of blood services with no working conditions), we can infer to Brazil that the probability of getting transfusion-transmitted Chagas disease is of $0.091 \times 10^{4}$, which would represent approximately thirty yearly; quite inferior values than those estimated at the end of the 70's (10 thousand yearly, Dias 1987).

\section{SOUTHERN CONE FIRST INITIATIVE}

The role played by the Pan-American Health Organization (PAHO) to control transfusion-transmitted Chagas disease and the development of hemotherapy in all South America, through the implementation of the program "Southern Cone Initiative", is fully known.

Under this Organization's support, the ministries of health from the countries that belong to the South Cone, during a meeting in Brasília, in July 1991, recognized the huge size of the problem and committed themselves to the eradication of $T$. infestants on the region and also to eliminate the transfusional transmission of T. cruzi, through strengthening the blood banks and through the effective control of donors (OPAS 1992, Dias \& Schofield 1998).

The South Cone Initiative defined that the pretransfusional serological control was mandatory in all countries, reserving the chemoprophylaxis practice (with gentian violet) to the hiper-endemic areas. To do so, it stimulated the creation of the blood law in each country, the increasing of serological screening coverage, the usage of two serological techniques of different principles, and the improvement of the achieved serology pattern. At least one annual technical meeting to assess the program was also established (Dias \& Schofield 1998).

When the program started in 1991, only Brazil, Argentina and Uruguay had legislation that compelled the donor's serological trial, although no one of them showed 100\% of coverage. In Chile, 
where serology started being an obligation only in endemic areas; the serological screening coverage in 1996 was of $98.9 \%$ in these areas and $76.9 \%$ all the country taken into consideration. Paraguay, little by little incorporated to the program its blood law being promulgated in 1996 (Dias \& Schofield 1998).

Bolivia showed the biggest number of positive blood donors in Latin America, only recently started to develop its program to control the vector and is on its first steps to organize its blood program (The Regional Blood Bank of Santa Cruz de La Sierra, the most endemic area was only opened last December). This view was very well assessed by Dias and Schofield in 1998 and during the VIII South Cone Intergovernmental Committee Meeting to eliminate the T. infestants and to control transfusion-transmitted Chagas disease, in Tarija, Bolívia (pers. inform.).

The work developed along this decade in the Southern Cone, changed the view of Chagas disease in the area and reduced very much the risk of transfusional transmission of this horrible disease.

\section{BRAZILIAN POLICY PROGRAM FOR BLOOD TRANSFUSION SAFETY}

Despite the clear improvement of our hemotherapy, socio-economic and cultural unlevels and the lack of commitment from our govern, we live, by one side, with the technical scientific excellency of several hemocenters, and some of the blood banks existing nowadays and, on the other side, the event of arm-to-arm transfusion in small communities and/or hospitals in Brazil.

The evolution of Brazilian public blood service, stimulated by financial resources, that, for the last three years summed up 56 millions dollars, make the bloodcenters and other hemotherapy services linked to them, be responsible for nearly $60 \%$ of all blood transfusion in the country.

The Brazilian Ministry of Health (through of Technical Advisory Committe/Cosah, from the Secretary of Policy - responsible for political structure regulation and implementation of the National Blood Program and of Federal Surveillance Group/ DISAH, from Secretary of Sanitary Surveillance, responsible for its inspection) goes through the strengthening of the structures responsible for formulation, regulation and control of activities (on a state and federal level), and above all, the units responsible for blood services (hemocenters, blood banks, transfusional agencies, etc.).

So this is that, to assure the transfusion safety, the Ministry of Health elected the blood quality its National Mobilizing Goal in Health Area, when the Federal Government re-launched the Brazilian Quality and Productivity Program (PBQP), on May
18, 1998. It was defined as follows: "Blood - 100\% with quality safety in all its process until 2003" (Cosah 1998).

For the ministry goal's choice, as well as its complete formulation, it was very important to mobilize and make all the community participate. The community represented by the managing agencies of the system on a federal and state level (Ministry of Health, through the secretaries that are closer linked to the National Health Blood Program and the State Secretaries of Health, through their State Blood Coordinations); by the blood services (directors and technicians from hemocenters and blood banks) the society (Colégio Brasileiro de Hematologia, Sociedade Brasileira de Hematologia e Hemoterapia, Sociedade Brasileira de Talassémicos and Federação Brasileira de Hemofilia); besides technicians from Instituto Nacional de Controle de Qualidade em Saúde, Departamento de Informática do Sistema Único de Saúde (Datasus), Fundação Oswaldo Cruz. More than a hundred of technicians from these agencies gave and are giving their contribution for this ambitious goal; that doesn't have any other objective than to give to all Brazilian people equal rights to the blood transfusion with quality.

To reach the proposed objectives this ministry goal was divided in twelve projects, that are:

- Re-formulating Brazil's National Policy Program;

- Implantation and Implementation of a National Blood Management Information System;

- Maintenance and Implementation of the Organizational and Physical Infra-structure of the Public Blood System;

- Implantation of Human Resources Qualification Program;

- Implementation of National Volunteer Blood Donor Program;

- Implementation and Implantation of Hemotherapy Services Credibility National Program;

- Encourage the Implantation and Implementation of the Total Quality Program and the Blood Quality National Award;

- Implementation of an External Quality Control Program in Imuno-hematology and Serology in Hemotherapy Services;

- Increase the Number of Sanitary Inspection in Blood Services;

- Quality Control Systematization of Used Testing Material and Reagents in Hemotherapy commercialized in Brazil;

- Re-structure the Sanitary Surveillance System.

The formulation of these projects is concluded and some of them are already being implanted, 
among them, by its narrow relation to the theme, we will point out the following:

Re-formulating Brazil's National Policy Program - Its aim is to define a single blood policy program for the country, that assures its availability, safety and quality, through the explicitation of govern's intentions in this area and which includes govern and society participation.

Implantation and implementation of a national blood management information system - This program was developed together with Datasus and it has as its aim create a National Information Net referring to blood and hemoderivatives, that will allow the various managers (federal, state, municipal) to reach the data needed to make decisions referring the management of the system, specially those concerning the public and private hemotherapy services, its production reports, clinic epidemiology and serologic profile of differed donors file and blood disease victims, mostly hemophiliacs and hemoglobinopaths.

Maintenance and implementation of the public organizational and physical infra-structure of public blood system - Nowadays, the Minitry of Health, through Cosah, is giving resources of 76 million of "reais". These resources for more than two hundred projects, defined and formulated by their respective federal units, are destined to the construction, rebuild and functional and managing modernization of the public blood services. This new project is being implemented with the objective of making a standard and redefining the increasing criteria of this National Blood Service, so that, reaching the most distant communities, assures the hemotherapy covering needed and the transfusion blood quality.

Implantation of human resources qualification program - This project has the aim of update and recycle the human resources in the hemotherapy and hematology areas (through specialization, improvement and recycling courses, in the country and abroad). It is implementing the TELELABBLOOD - distant training program, a partnership with the DST/Aids Coordination (Aids -Sexually Transmitted Diseases Coordination), supported by booklets and video-tapes, the TELELAB-BLOOD is training, since 1999 nearly 30 thousand technicians all over the country. Fourteen courses will be offered and the first ten from the following list are already being used: (1) donors blood collecting; (2) hemocomponents preparation; (3) Chagas disease: screening and serologic diagnosis in hemotherapy services and public health laboratories; (4) viruses hepatitis: screening and serologic diagnosis in hemotherapy services and public health laboratories;

(5) HTLV-
I/II: screening and serologic diagnosis in hemotherapy services and public health laboratories; (6) HIV serologic diagnosis (re-edition of TELELAB-I); (7) syphilis serologic diagnosis (reedition of TELELAB-I); (8) serologic tests quality control in hemotherapy services and public health laboratories; (9) equipment: usage and monitoring in hemotherapy services and public health laboratories; (10) bio-safety in hemotherapy services and public health laboratories; (11) immunohematology: routine in hemotherapy services; (12) donors attraction: $90 \%$ reliable volunteers, as slogans; (13) hemotherapy: components and blood indication; (14) hemotherapy: transfusion reactions - how to identify and how to treat.

The expectation is that, with the implementation of Health Area National Mobilizing Goal, in Health Area, Brazil may count, in the first years of next millennium, on a hemotherapy structure of universal coverage, that will assure self-sufficiency in blood, components and derivatives, with the quality standard from developed countries, committed to the population's longings and needs, and that the transmission of diseases, via blood transfusion, as Chagas disease, will be a rare event, inherent only to ineffability of biological procedures and processes.

\section{REFERENCES}

Cosah - Coordenação de Sangue e Hemoderivados, Departamento de Gestão de Políticas Estratégias da Secretaria de Políticas de Saúde do Ministério da Saúde. Relatório das atividades, 1998, 26 pp.

Dias JCP 1987. Control of Chagas disease in Brazil. Parasitol Today 3: 336-341.

Dias JCP, Brener S 1984. Chagas disease and blood transfusion. Mem Inst Oswaldo Cruz 79 (Suppl.): 139-147.

Dias JCP, Schofield CJ 1998. Transfusional transimission control of Chagas disease in the Southern Cone Iniciative. Rev Soc Bras Med Trop 31: 373-383.

Freitas JLP, Amaro Neto V, Sonntag R, Biancalana A, Nussenzweig V, Barreto JG 1952. As primeiras verificações de transmissão acidental da moléstia de Chagas ao homem por transfusão de sangue. Rev Paulista Med 40: 36-40.

Moncayo A 1992. Chagas disease: epidemiology and prospects for interruption of transmission in the Americas. World Health Stat Q 45: 276-279.

Mazza S, Montana A, Benitez C, Janzi EZ 1936. Transmissión del Schizotryponum cruzi al niño por leche de la madre com enfermedad de Chagas. MEPRA 28: 41-46.

Moraes-Souza H 1985. Estudo do Metabolismo e Viabilidade do Sangue Fresco e Preservado Tratado pela Violeta de Genciona, PhD Thesis, São Paulo.

Moraes-Souza H, Bordin JO 1996. Strategies for prevention of transfusion associated Chagas disease. Transf Med Rev 10: 1-11.

Moraes-Souza H, Wanderley DMV, Brener S, 
Nascimento RD, Antunes CM, Dias JCP 1994. Hemoterapia e doença de Chagas transfusional no Brasil. Bol Of Sanit Panamericana 116: 406-418.

Nussenzweig V, Sonntag R, Biancalana A, Freitas JLP, Amato Neto V, Kloetzel J 1953. Ação dos corantes tri-fenil-metânicos sobre o Trypanossoma cruzi in vitro: Emprego da violeta de genciana na profilaxia da trasmissão da moléstia de Chagas por transfusão de sangue. Hospital 44: 731-744.

OPS - Organização Panamericana da Saúde 1992. OPS. PNSP/92-18 sobre a Iniciativa do Cone Sul. Washington DC, Mimeo, $12 \mathrm{pp}$.

Pellegrino J 1949. Transmissão da doença de Chagas por transfusão de sangue: Primeiras comprovações sorológicas em doadores e candidatos e doadores. Rev Bras Med 6: 297-301.

Portaria 07/80/MS 1980. Diretrizes básicas do programa nacional de sangue e hemoderivados - Pró-Sangue. Portaria 1376/93/MS 1993. Normas técnicas para coleta, processamento e transfusão de sangue, componentes e derivados, $77 \mathrm{pp}$.

Resolução 130/96/Mercosul 1999. Regulamento técnico de medicina transfusional (Versão revisada), $50 \mathrm{pp}$.

Schmunis GA 1991. Triponosoma cruzi, the etiologic agent of Chagas disease: status in the blood supply in endemic and non endemic countries. Trasnfusion 31: 547-555.

Schmunis GA, Zicker F, Pinheiro F, Brandling-Bennett 1998. Risk for transfusion transmitted infections diseases in Central and South America. Emer InfDis 4: 5-11.

Soto V B 1940. Consideraciones sobre la epidemiologia de la enfermedad de Chagas en Chile y su profilaxia. Bol Med Soc 77: 565-634. 